\title{
Analysis and Exploration of Multimedia Assisted College English Second Classroom Teaching Model
}

\author{
Xu Wei \\ Wuhan Donghu University, Wuhan 430212, China
}

Keywords: Multimedia; College English; Second classroom; Teaching mode

\begin{abstract}
College English second classroom teaching is an important part of the entire university education system, educational administration department should be included in the school's normal teaching management scope. Broaden college English second classroom activity form for extracurricular activities effectively complement classroom, to give students more opportunities for language practice, improve the interest in learning English, open field of vision, to create a strong atmosphere of learning English, improve listening, speaking, reading and writing comprehensive ability and language practice ability, to realize the goal of college English teaching and improve the comprehensive quality of college students and provide a strong guarantee. This article will explore the multimedia assisted college English second classroom teaching mode.
\end{abstract}

\section{Introduction}

As the appearance of disadvantages and problems of traditional class foreign language teaching, domestic scholars pay more and more recognition and attention to second foreign language class teaching, and study it from various perspectives, but most of the achievements are concentrated on the importance of the second classroom teaching and the discussion of specific language in the form of second classroom teaching [1]. In a word, people consider foreign language second class as the extension of class foreign language teaching, could create deeper foreign language learning atmosphere, almost real context. It is the window for students to understand the foreign culture, the important way to ensure follow-up foreign language teaching in university, an important force in the construction of campus culture and so on. In addition to those, the particular form of the second classroom for foreign language teaching, the researchers also noted that the foreign language website, foreign language festival, lectures, all kinds of competitions, and so on.

\section{The significance of carrying out second classroom in college English}

Firstly, second classroom in college English, after incorporated into the whole education system, is treated as other courses in the use of money, equipment, venues and teaching management and so on to get necessary, timely arrangements to guarantee of college English second classroom teaching order and persistence on the hardware [2].

Second, many teachers of their own professional ethics, love of students and school for college English second classroom teaching also need a lot of time and energy, make a lot of efforts without any pay for college English second classroom teaching. Bringing the college English second classroom teaching into the whole teaching system, on the one hand, can calculate the reasonable effort to teachers who in charge of the second classroom English teaching, fully approving their efforts and enhancing their working enthusiasm; on the other hand, the process and effect of college English second classroom teaching could be supervised and inspected and the rationality and efficiency of college English second classroom teaching could be ensured.

Finally, we need to bring the college English second classroom teaching into the whole teaching system, and build suitable and dynamic evaluation system, completing the credit system of the second classroom English, making unitive rules and objective appraisal for students to participate in 
the second classroom English teaching activities-- students should according to the specific of the second classroom activities, combined with their own interests, special skills and English ability, to take part in the English second classroom activities with reasonable arrangement and obtain corresponding credits.

\section{Problems of second classroom in college English}

(a) Less students participated

College English second classroom teaching is an important part of college English teaching, and the teaching object is all students in the school, but in the actual, only a few students participate in the English second classroom teaching, most of students fail to get English cultural knowledge and application ability. Students who attend college English second classroom are most freshman and sophomore students, senior students are difficult to participate in similar learning activities for they have completed the syllabus of college English course. Ultimately, college English second classroom becomes a stage of few students which does not play its proper role [3].

(b) Lack of faculty, instructions and management

College English second classroom teaching, like other instructional mode, with its own theoretical basis and inherent characteristic, needs to develop in accordance with the law of development and adhere to certain objective requirement, so it is necessary to equip with a certain amount of faculty to make systematic management and the correct guidance. However, due to the restriction of mentality, insufficient funds, and shortage of teachers, according to our survey, many universities have not prepared special and long-term teachers to make guidance and management for college English second classroom teaching.

(c) Insufficient funds and activity space configuration

The second classroom activities can only be operated in the clearance of those non-second classroom activities, and some places need to be examined and approved by many sections-- office of teaching affairs office of person, organization department and security department—all above set up a barrier to the development of college English second classroom. In addition, insufficient funds weight against this pedagogical practice [4].

\section{College English second classroom teaching strategies assisted by multimedia}

(a) Adopting modernized management means on second classroom teaching

When managing second classroom teaching practice, relevant competent departments of faculty and universities need to try to use modern management means such as multimedia and computers to set up certain scale, detailed and complete information base and database about second classroom teaching practice; to formulate and perfect the system of information collection and data filing; what is more, record, count and analyze all types of information of the second classroom teaching practice activities. In this way, it will provide more convenience for scientific research, summary and improvement of second classroom teaching practice.

(b) Using new media to carry out second classroom teaching activities

With the development of multimedia network technology, the dialogue is not limited to teachers-students and students-students: there are different kinds of teaching environment born at the right moment-- interactive class between teachers and students, students-students interactive "community", students-computer interactive "online” teaching environment. In class, places for students extra-curricular activities, network virtual space 3D environment, such as WeChat "Circle of Friends" and QQ video Hangouts, etc. In English interactive activities between teachers-students, students-students and students-computers, teachers play the role of guiding, promoting and coordinating, but students play the main role. By means of exploration, practice and cooperation to study in practice and exploration to gradually complete understanding and externalization of the rules of language use, at the same time, we can carry out second classroom activities as an extension of teaching and learning [5]. 
(c) Optimizing the second classroom teaching resources

Compared with the traditional classroom mode, the multimedia teaching practice optimizes foreign language teaching resources environment, improving the efficiency of individual learning and teaching effect, and thus shows its broad prospects of development. Multimedia teaching mode not only uses advanced technology methods to improve the teaching efficiency. More important, it changes the traditional teacher-centered teaching mode, forming student-centered personalized learning styles. This brand new teaching mode-- changing roles between teachers and students pays more attention to "learning" rather than "teaching" , gives play to a far-reaching significance of developing and cultivating foreign language comprehensive application ability and individual and independent learning capability of Chinese students [6].

\section{Acknowledgements}

The exploration and practice of English "Second Class"------A case study of Wuhan Donghu University English FM Radio Station’ s broadcasting program .

\section{Conclusion}

Second classroom of college English in universities is important for college English teaching effects, as the extension of classroom teaching, what second classroom taught is the digest, understanding, absorption and sublimation of course content. The second classroom is an important part of the whole teaching system in the university and faculty, another indispensable growing environment provided by them.

\section{Reference}

[1] Wu Di, Liu Gailin. Feasibility Study of College English Second Classroom Teaching Under the Trend of “Internet +” [J]. Education \& Teaching Forum, 2017, (04):261-262.

[2]Fan Fei. First Exploration of College English Second Classroom Teaching Design Effectiveness - Based on Needs Analysis Theory and Professional Learning Perspective[J]. Education Science \& Culture Magazine(the first ten-day period of a month),2016,(11):167-169.

[3]Hu Jianan, Lu Ting. Research on The College English Second Classroom Construction to Enhance University Students' Employment Competitiveness [J]. Journal of Hunan Institute of Science and Technology, 2016,(11):142-144.

[4]Tang Chunyan. Analysis of Problems of Higher Vocational College English Second Classroom Construction Under the Education Ecology View [J]. Overseas English, 2016,(17):25-26.

[5]Zhao Yun. Discussion on Information Network Technology Applied in College Oral English Teaching in Second Classroom Construction [J]. Journal of Hubei Correspondence University, 2016,(19):144-145.

[6]Guo Qi, Xu Chunling. Exploration and Practice of Innovation Model of College English Second Classroom Activities under the Background of Educational Reform - taking Huaqiao University as an example[J]. Overseas English, 2016,(04):73-74. 